\title{
Modeling of Pressurized Electrochemistry and Steam- Methane Reforming in Solid Oxide Fuel Cells and the Effects on Thermal and Electrical Stack Performance
}

\section{KP Recknagle}

MA Khaleel

March 2009

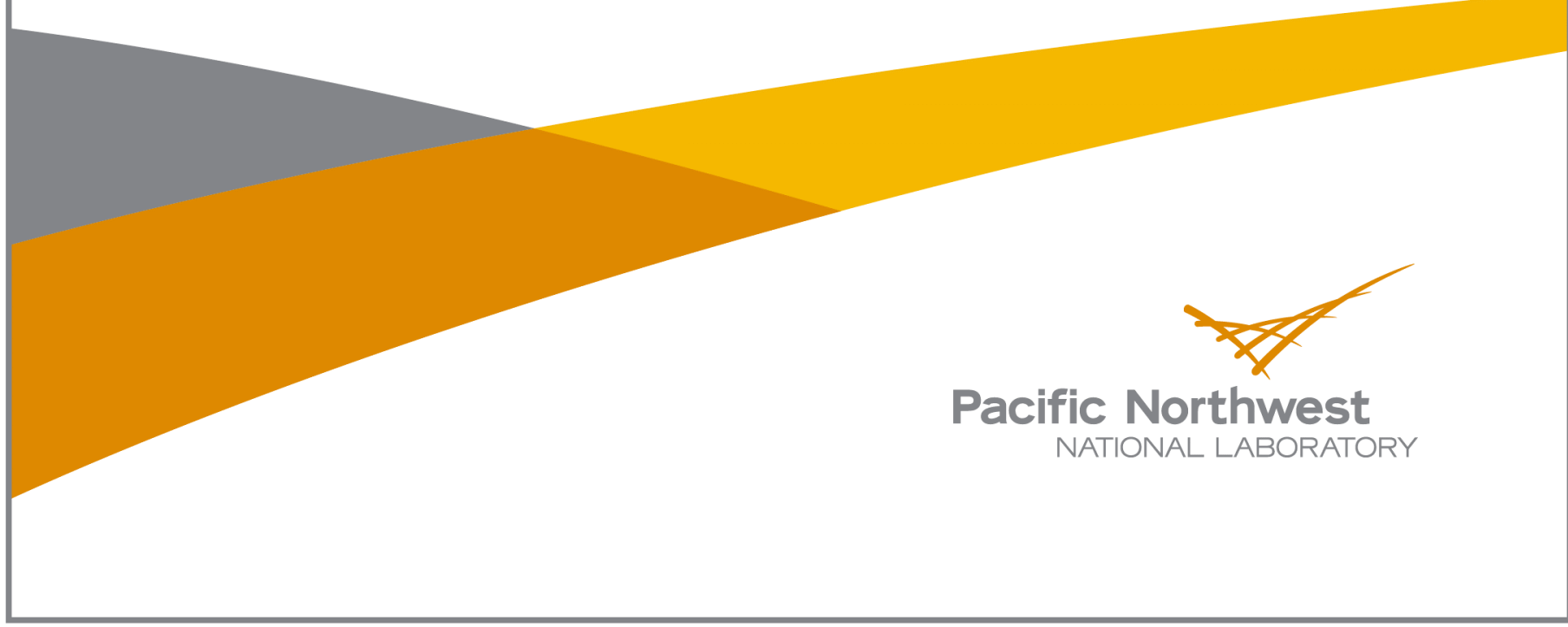




\title{
DISCLAIMER
}

This report was prepared as an account of work sponsored by an agency of the United States Government. Neither the United States Government nor any agency thereof, nor Battelle Memorial Institute, nor any of their employees, makes any warranty, express or implied, or assumes any legal liability or responsibility for the accuracy, completeness, or usefulness of any information, apparatus, product, or process disclosed, or represents that its use would not infringe privately owned rights. Reference herein to any specific commercial product, process, or service by trade name, trademark, manufacturer, or otherwise does not necessarily constitute or imply its endorsement, recommendation, or favoring by the United States Government or any agency thereof, or Battelle Memorial Institute. The views and opinions of authors expressed herein do not necessarily state or reflect those of the United States Government or any agency thereof.

\author{
PACIFIC NORTHWEST NATIONAL LABORATORY \\ operated by \\ BATTELLE \\ for the \\ UNITED STATES DEPARTMENT OF ENERGY \\ under Contract DE-AC05-76RL01830
}

Printed in the United States of America
Available to DOE and DOE contractors from the
Office of Scientific and Technical Information,
P.O. Box 62, Oak Ridge, TN 37831-0062;
ph: (865) 576-8401
fax: (865) 5765728
email: reports@adonis.osti.gov

\author{
Available to the public from the National Technical Information Service, \\ U.S. Department of Commerce, 5285 Port Royal Rd., Springfield, VA 22161 \\ ph: (800) 553-6847$$
\text { fax: (703) 605-6900 }
$$ \\ email: orders@nits.fedworld.gov \\ online ordering: http://www.ntis.gov/ordering.htm
}




\section{Modeling of Pressurized Electrochemistry and Steam- Methane Reforming in Solid Oxide Fuel Cells and the Effects on Thermal and Electrical Stack Performance}

KP Recknagle

MA Khaleel

March 2009

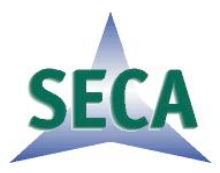

Prepared for the U.S. Department of Energy under Contract DE-AC05-76RL01830 



\section{Executive Summary}

This report summarizes work done to extend the electrochemical performance and methane reforming submodels to include the effects of pressurization and to demonstrate this new modeling capability by simulating large stacks operating on methane-rich fuel under pressurized and nonpressurized conditions. Pressurized operation boosts electrochemical performance, alters the kinetics of methane reforming, and affects the equilibrium composition of methane fuels. This work developed constitutive submodels that couple the electrochemistry, reforming, and pressurization to yield an increased capability of the modeling tool for prediction of solid oxide fuel cell (SOFC) stack performance.

The electrochemistry model was advanced to characterize the increased SOFC performance due to diminished activation polarization. The activation polarization depends upon the exchange current density between the electrodes and electrolyte. The exchange current density is increased by elevated pressure resulting in decreased polarization loss. The Nernst potential is also increased with pressure, and, when augmented by the decreased polarization, provides increased cell voltage and stack power.

The operating pressure has competing effects on reformation; it increases the methane conversion rate while also increasing the equilibrium methane concentration. The methane conversion rate expression developed by this work accounted for these effects. The rate expression used equilibrium gas compositions for temperatures ranging from $650^{\circ}$ to $850^{\circ} \mathrm{C}$ and pressures of 1 to 10 atmospheres, and incorporated the steam-methane reaction equation. The gas compositions were used to calculate the equilibrium constant, and the reforming reaction equation established the form of the forward and backward terms. The combination of these elements resulted in an expression of the overall conversion rate that correctly accounts for the pressurization effect on the kinetics and the reverse reaction.

The models accounting for the pressure effects on the electrochemistry and methane reforming were applied in stack simulations to examine how they can potentially change the distributions of fuel, air, current density, temperature, and reforming rates within large area stacks. An ordinary $20 \times 20-\mathrm{cm}$ cross-flow stack model geometry was used as a generic example of a "large" planar stack to demonstrate how the modeling tool can be applied to any proposed stack design for a similar analysis. We expect differences in the scalar distributions depending upon the size and configuration of the stack. We also expect the trends of pressurization effects on the reforming rates, temperatures, current density, gas concentrations, and pressure drops would be the same for any other planar stack under pressurized operation. Cases of operating pressures ranging from 1 to 10 atmospheres and 2 reformation rates differing by a factor of 10 were simulated. The predictions showed consistently increased electrical performance for both reforming rate cases with increased operating pressure. The overall thermal performance, as indicated by maximum temperature and temperature difference, was generally improved for operating pressures above 2.5 atmospheres. At 10 atmospheres, for both reforming rates, the maximum temperature had decreased by about $4 \%$, the temperature difference had decreased by $28 \%$, and the cell voltage increased by $10 \%$ compared to the atmospheric fast reforming case. 



\section{Acknowledgments}

Pacific Northwest National Laboratory is operated by Battelle for the U.S. Department of Energy under Contract DE-AC05-76RL01830. The work summarized in this paper was funded as part of the

Solid-State Energy Conversion Alliance (SECA) Core Technology Program by the U.S. Department of Energy's National Energy Technology Laboratory (NETL). 



\section{Contents}

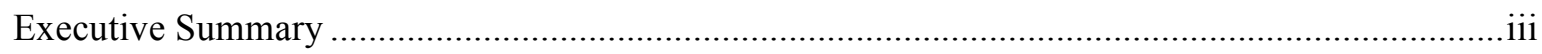

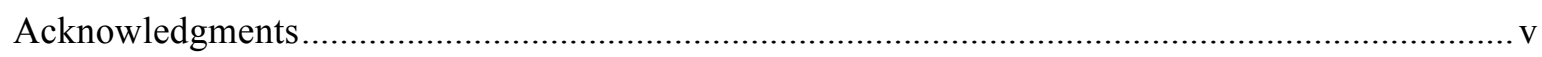

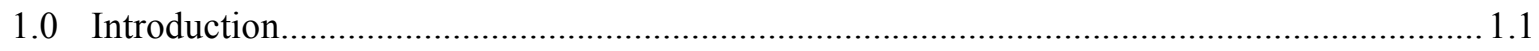

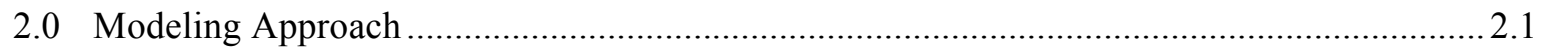

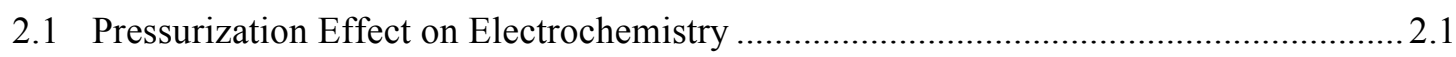

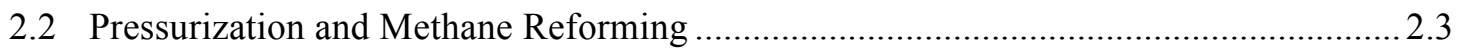

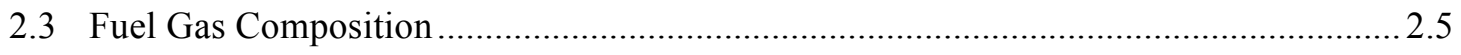

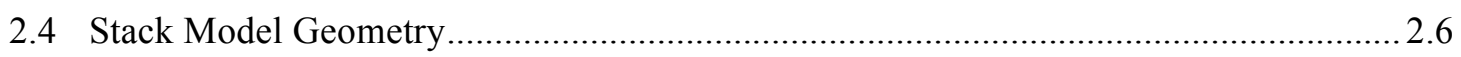

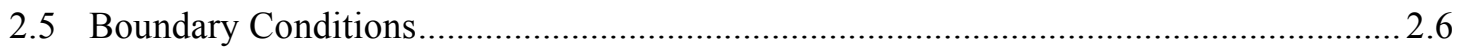

2.6 Electrochemical Performance and Material Properties .............................................. 2.7

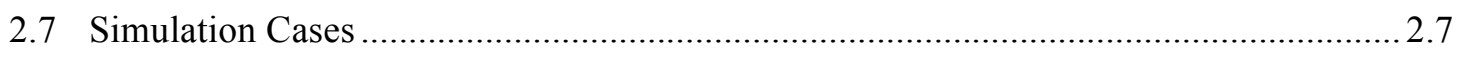

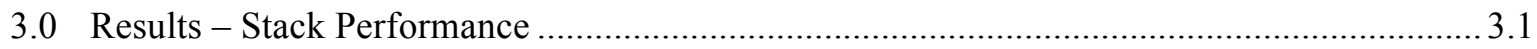

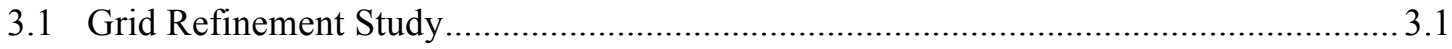

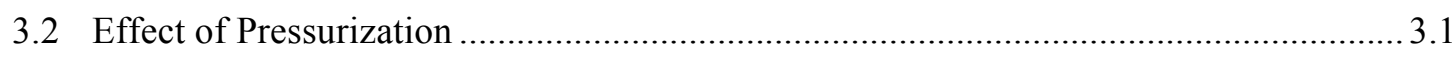

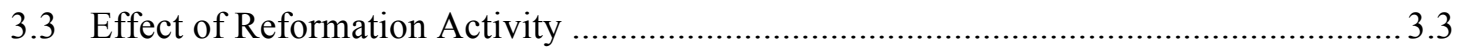

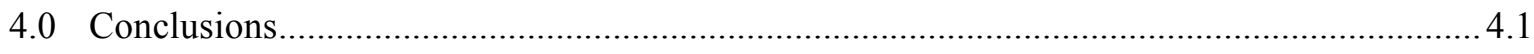

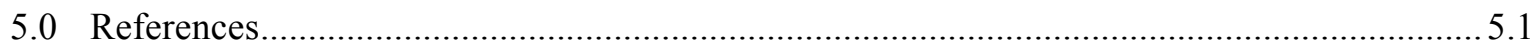

Appendix - Analysis of the Computational Mesh ........................................................................ A.1 


\section{Figures}

2.1. Electrochemical Performance of a) Tubular Cell Operating on $89 \% \mathrm{H}_{2}, 3 \% \mathrm{H}_{2} \mathrm{O}$, Running at 1,3 , and 10 atm at Constant $85 \%$ UF and b) Planar Cell Operating on $97 \% \mathrm{H}_{2}, 3 \% \mathrm{H}_{2} \mathrm{O}$,

Running at 1, 3, and 10 atm at Constant Fuel Flow

2.2. Equilibrium Concentrations of a) Methane and b) Hydrogen Based on Input Gas Mixture of $26.3 \% \mathrm{H}_{2}, 49.3 \% \mathrm{H}_{2} \mathrm{O}, 2.9 \% \mathrm{CO}, 4.4 \% \mathrm{CO}_{2}$, and $17.1 \% \mathrm{CH}_{4}$

2.3. Equilibrium Constant for the Steam-Methane Reformation Reaction, $\mathrm{mol} / \mathrm{m}^{3}-\mathrm{s}-\mathrm{atm}^{2}$

2.4. Exploded Assembly of the Baseline Stack Model Including Lower Separator Plate, Cathode Flow Region/Interconnect, Lower Seal, Cell, Upper Seal, Anode Flow Region/Interconnect, and Upper Separator Plate

3.1. Pressurized Stack Simulation Results for Internal Reforming and Operating Pressures of 1 to $10 \mathrm{~atm}$ and Profiles of Mass Concentration of a) Methane and b) Hydrogen

3.2. Pressurized Stack Simulation Results for Internal Reforming and Operating Pressures of 1 to $10 \mathrm{~atm}$ and Profiles of a) Normalized Temperature and b) Anode Temperature $2.5 \mathrm{~mm}$ downstream of the leading edge $\left({ }^{\circ} \mathrm{C}\right)$

3.3. Pressurized Stack Simulation Results for Internal Reforming and Profiles of Electrical Current Density Along a Fuel Stream Line on the Anode for Pressures of 1-10 atm

3.5. Axial Temperature Distributions for Internal Reforming Cases with Standard Methane Conversion Activity and for 10 Times Slower than Standard Activity at Operating Pressures of 2.5 and 10 atm

\section{Tables}

2.1 Thermal Properties Used in the Simulations

3.1 Predicted Thermal and Electrical Performance of 20x20-cm Generic Cross-Flow Stack Cases with on-Cell Methane Reformation and Pressurized Operation (average cell temperature $750^{\circ} \mathrm{C}$, average current density $0.6 \mathrm{~A} / \mathrm{cm}^{2}$ ) 


\subsection{Introduction}

The trend in the solid oxide fuel cell (SOFC) industry continues toward the development of larger, more powerful stacks for stationary power applications. The primary fuel source for these large systems will be coal gas. For such stacks and systems, thermal management remains a critical issue for reliable operation. Stable electrochemical performance of the electrodes, electrical performance of the contact materials, and thermal-mechanical performance of these materials (particularly interconnects and seals) depend in part on the maximum temperature they experience under long-term operation. The materials perform more stably with lower maximum temperatures. With respect to initial stack performance, stresses will be present within the stack materials and interfaces due to thermal gradients, temperature differences, and thermal expansion mismatches created by deviations from the stress-free temperature. Differences in temperature within the stack (and the cell) are created by cooling the stack with inflowing cathode air and fuel on one hand and the net heat load resulting from the electrochemical reactions on the other. Assuming a consistent average stack operating temperature of $750^{\circ} \mathrm{C}$, roughly midway between minimum and maximum, when the difference between the minimum and maximum cell temperatures $(\Delta \mathrm{T})$ is decreased, the maximum temperature $\left(\mathrm{T}_{\max }\right)$ will also be decreased. Isothermal stack operation is the ideal condition that stack builders seek; however, it can be technically challenging to achieve this condition for larger cells because the heat removal paths increase with increasing cell size. Increased cathode air flow can help mitigate unacceptably high temperatures and thermal gradients, but are accompanied by unacceptable increases in parasitic power loss and reduced efficiency.

Previous work sought to optimize thermal and electrical stack performance by manipulating parameters that affect stack temperature, including fuel and air utilization, anode and separator plate thickness, and temperature of stack surroundings (Recknagle et al. 2007). The study showed the benefits possible with increased cathode air delivery, decreased fuel utilization, and improved thermal conductivity in the separator plates. That work was done under the constraints that the stack was operated at atmospheric pressure with no methane in the fuel for reformation cooling. The present model development work was done to lift these constraints and enable simulation of stacks operating at elevated pressure with the effects on the electrochemistry and on-cell steam-methane reformation.

Steam-methane reformation occurs in the presence of a nickel catalyst, where methane and steam are converted to hydrogen and carbon monoxide according to the endothermic steam-methane reformation reaction (Eq. 1.1). When the reformation reaction occurs on the nickel anode it uses heat generated by the electrochemical reactions directly, thus decreasing the net heat load. Decreased heat load is favorable from the thermal management perspective. A second reaction involved in reformation is the exothermic water-gas-shift (WGS) reaction (Eq. 1.2), which seeks equilibrium rapidly during reformation and decreases the reformation endothermic effect to some degree.

$$
\begin{array}{rr}
\mathrm{CH}_{4}+\mathrm{H}_{2} \mathrm{O} \Leftrightarrow 3 \mathrm{H}_{2}+\mathrm{CO} & \Delta \mathrm{H}_{298}=206 \mathrm{~kJ} / \mathrm{mol} \\
\mathrm{CO}+\mathrm{H}_{2} \mathrm{O} \Leftrightarrow \mathrm{H}_{2}+\mathrm{CO}_{2} \quad \Delta \mathrm{H}_{298}=-41.1 \mathrm{~kJ} / \mathrm{mol}
\end{array}
$$

Pressurization boosts the electrochemical performance and electrical power output. Increased power and efficiency translates into decreased heat load. The reformation reaction favors high temperature and low pressure. In the forward reaction, the volume of reactant gases converts to generate double the volume of product gases. Therefore, low pressure favors the forward reaction and high pressure favors 
the reverse reaction. Thus, proper choice of SOFC operating pressure could potentially be used to slow the reformation to a rate that improves the conditions for thermal management of the stack.

The objective of this work was to advance the electrochemical performance and methane reforming submodels to include the effect of pressurization, then to demonstrate this new modeling capability by simulating large stacks operating on methane-rich fuel under pressurized and nonpressurized conditions. The subsequent sections of this report describe effects of pressurization on the electrochemistry and steam reforming, with discussions of the constitutive models used to characterize the effects in Section 2. The stack model is described in Section 3, followed by simulation results; conclusions and recommendations for further work on this topic are presented in Section 4. Cited references are included in Section 5. 


\subsection{Modeling Approach}

The PNNL developed SOFC-MP solves the equations for mass transport, energy, and electrochemistry required to predict the fluid flow, temperature, species, and current density distributions in a three-dimensional SOFC geometry (Khaleel 2005, Khaleel et al. 2004, Recknagle et al. 2003). The electrochemistry model was described by Chick et al. (2000), calibrated for application to planar stack simulations (Chick et al. 2002, Keegan et al. 2002), and updated to provide an improved anode concentration polarization model (Williford et al. 2003). The capability was expanded to incorporate steammethane reforming for simulating on-cell reformation cooling (Recknagle et al. 2004, 2006), and later updated with a rate expression derived experimentally at Pacific Northwest National Laboratory (PNNL) (King et al. 2005). To include the effect of pressurization, an expansion of the existing stack modeling capability was required. Revisions to the electrochemical and steam reforming submodels were needed to capture the physics associated with pressurized stack operation.

The following approach was taken to advance the SOFC modeling capability and demonstrate the advancements by performing pressurized, reforming stack simulation cases:

- Examine the pressurization effect on SOFC electrochemistry and incorporate constitutive submodels to characterize the performance changes.

- Develop a constitutive submodel of the pressurized steam-reforming kinetics while accounting for the effect of pressure for the case with equilibrium gas composition.

- Perform simulation cases of stacks receiving methane-rich fuel for reformation cooling and operating at pressures of 1 to 10 atmospheres (atm).

- Examine sensitivity to reformation kinetics by simulating pressurized cases with a baseline rate and a rate $1 / 10^{\text {th }}$ of the baseline.

The thermal performance for this study was evaluated based on the predicted maximum cell temperature. The electrical performance was based on the predicted cell voltage.

\subsection{Pressurization Effect on Electrochemistry}

The maximum ideal open circuit potential in the SOFC is due to the difference in oxygen chemical potential between the cathode and anode interfaces with the electrolyte. This is the Nernst potential and can be expressed as a function of the partial pressure of oxygen at the anode- and cathode-electrolyte interfaces:

$$
V_{\text {Nernst }}=\frac{R T}{4 F} \ln \left(\frac{P_{O_{2}, \text { cathode }}}{P_{O_{2}, \text { anode }}}\right)
$$

where $R$ is the universal gas constant $(8.314 \mathrm{~J} / \mathrm{mol}-\mathrm{K})$, $\mathrm{T}$ is the temperature in Kelvin, and $F$ is Faraday's constant $(96485 \mathrm{~A}-\mathrm{s} / \mathrm{mol})$. The Nernst potential for the combination of cathode air and wet hydrogen (i.e., $97 \% \mathrm{H}_{2}, 3 \% \mathrm{H}_{2} \mathrm{O}$ ) on the anode is about 1.07 volts at $750^{\circ} \mathrm{C}$. The Nernst potential is decreased for fuels containing increased $\mathrm{H}_{2} \mathrm{O}$ vapor pressure (such as reformed or recycled tail gas fuels) because of the subsequently increased $\mathrm{O}_{2}$ vapor pressure in the fuel stream. 
The electrochemistry of an SOFC stack is described using a current-voltage (I-V) relation for the local conditions in terms of effective cell properties and operational parameters. This I-V relation is specific for the materials, gas compositions, pressure, and temperature of a given cell (Kim et al. 1999, Chick et al. 2000, 2002):

$$
V(i)=V_{\text {Nernst }}-i R_{i}-V_{\text {act }, e l}-V_{\text {cath }}-V_{\text {anode }}
$$

In the I-V relation, $i$ is the current, $R_{i}$ is the total ohmic resistance, $V_{\text {act,el }}$ are the electrode activation polarizations, and $V_{\text {cath }}$ and $V_{\text {anode }}$ are the electrode concentration polarizations. The ohmic resistances are formulated for each of the cell layers and stack components as described by Kim (1999). The activation polarization is controlled by the electrode reaction kinetics and represents the voltage loss incurred due to initiating charge transfer. It is related to the current density and the exchange current density by the phenomenological Butler-Volmer equation, written by Sawata et al. (1990) as

$$
i=i_{0}\left[\exp \left(\frac{2 F \eta_{a c t, e}}{R T}\right)-\exp \left(-\frac{\alpha_{e} F \eta_{a c t, e}}{R T}\right)\right]
$$

where $F$ is Faraday's constant of 96485 coulomb $/ \mathrm{mol}$ (or A-s $/ \mathrm{mol}$ ). For the SOFC cathode, the charge transfer coefficient $\alpha_{e}$ is equal to 2. As such, Eq. (2.3) can be written as

$$
\eta_{a c t, e l}=\frac{R T}{\alpha F} \sinh ^{-1}\left(\frac{i}{2 i_{0}}\right)
$$

in which $\alpha$ is a constant. The exchange current density $i_{0}$ has an associated pre-exponential factor $\left(\beta_{a c t}\right)$, activation energy $\left(E_{a c t}\right)$, and dependence on the partial pressure of oxygen $\left(P_{O 2, e l}\right)$ within the electrode:

$$
i_{0}=\beta_{a c t} \exp \left(\frac{-E_{a c t}}{R T}\right) P_{O_{2, e l}}^{\gamma}
$$

When an SOFC is pressurized, the Nernst potential (Eq. 2.1) will increase based on the partial pressure of oxygen at the electrode-electrolyte interfaces. Oxygen partial pressure on the cathode side is increased proportional to the increase in cathode air pressure. Oxygen partial pressure on the anode side does not increase with increasing fuel pressure, but rather is determined by the hydrogen and water partial pressures and the water vapor equilibrium constant. Partial pressures of the fuel species increase proportionally with fuel pressurization. Hence oxygen partial pressure in the anode will not increase strictly due to increased fuel pressure.

Data collected by Singhal (2000) during pressurized operation of tubular SOFCs showed that the cell voltage increase was larger than that attributable to the increased Nernst potential alone. The additional performance improvement was a result of decreased activation and cathode concentration polarizations. Concentration polarization depends upon the gas diffusivities, and on the porosity, tortuosity, and thickness of the electrode. Increased thickness or tortuosity will increase the polarization. Singhal's tubular cells had 2-mm-thick cathodes that had substantial concentration polarization. However, operating the cells at elevated pressure decreased the polarization. In the case of an anode supported 
planar SOFC, the cathode is much thinner (20 to $30 \mu \mathrm{m}$ ), making cathode concentration polarization less dominant. Unlike concentration losses the activation polarization is independent of the bulk electrode thickness and instead depends upon the electrode-electrolyte interface conductivity of both the air and fuel electrodes (Iwata et al. 1990) and the exchange current density. Sawata et al. (1990) found that the exchange current density (Eq. 2.5) depends on the oxygen partial pressure on both electrode-electrolyte interfaces and examined the activation polarization in each electrode.

In the anode, the charge transfer coefficient in Eq. (2.3) is equal to 1. In the present work it is assumed that when $\alpha_{e}$ is equal to 1, Eq. (2.3) can be approximated by Eq. (2.4). This is a reasonable assumption because the error introduced by assuming this form is small, and the model requires fitting to data using adjustable parameters. Hence Eq. (2.4) is applied to both the anode and cathode in the model. Thus in Eq. (2.5) the pre-exponential $\beta_{a c t}$, activation energy $E_{a c t, e}$, and $\gamma$ values are electrode-specific. The exponent for the partial pressure of oxygen $(\gamma)$ for the cathode has consistently been found to be about 0.5. For the anode, values for $\gamma$ range from 0.133 (Nagata et al. 2001) to 0.15 (Sawata et al. 1990).

This two-electrode activation polarization model, used in conjunction with the electrochemical performance model can fit myriad cell performance data for the purpose of stack simulations. Figure 2.1 demonstrates the flexibility of the model by showing it fit to Singhal's (2000) constant fuel utilization tubular (cathode-supported) data, as shown in Figure 2.1a, and to Minh's (2002) planar (anode supported) data, as shown in Figure 2.1b.

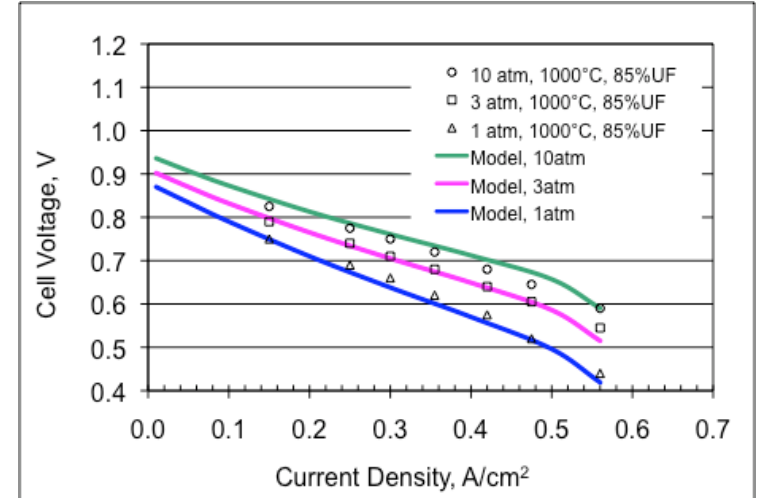

(a)

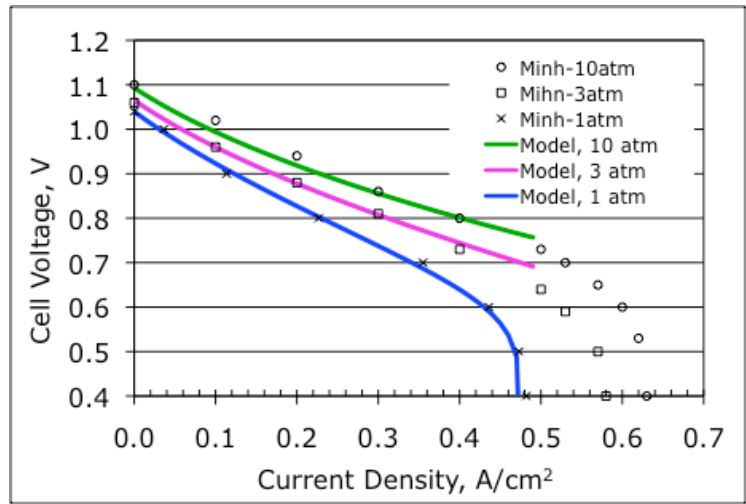

(b)

Figure 2.1. Electrochemical Performance of a) Tubular Cell Operating on $89 \% \mathrm{H}_{2}, 3 \% \mathrm{H}_{2} \mathrm{O}$, Running at 1,3 , and $10 \mathrm{~atm}$ at Constant $85 \%$ UF and b) Planar Cell Operating on $97 \% \mathrm{H}_{2}, 3 \% \mathrm{H}_{2} \mathrm{O}$, Running at 1, 3, and $10 \mathrm{~atm}$ at Constant Fuel Flow

\subsection{Pressurization and Methane Reforming}

An additional effect of pressurization is to increase the equilibrium concentration of methane according to the reformation reaction (Eq. 1.1). By Le Chatelier's principle, the reverse reaction is favored when the pressure is increased as the number of gas molecules and pressure are minimized. Using kinetics models derived from testing data, a one-dimensional anode diffusion and permeation gas transport model, and electrochemical reaction boundary conditions at the anode-electrolyte interface, Lehnert et al. (2000) calculated that manipulation of anode porosity and tortuosity could slow the reformation reaction by as much as $20 \%$. Gemmen and Trembly (2006) used a similar approach to consider the effect of pressurization. Their model predicted an increase in methane and decrease in 
hydrogen within an anode structure for operating pressures above $8 \mathrm{~atm}$. This equilibrium effect of pressure on the gas composition was taken into account while assembling the present pressurized reformation rate expression.

To formulate the pressurized rate expression, the commercially available and validated chemistry code Roine (2002) was used to calculate equilibrium gas compositions for temperatures ranging from $650^{\circ}$ to $850^{\circ} \mathrm{C}$ and pressures from 1 to $10 \mathrm{~atm}$. The concentrations of methane and hydrogen for these conditions are plotted in Figures 2.2a and 2.2b. Methane concentration was decreased and hydrogen increased with increased temperature, and, as expected, the methane was increased with increased pressure at any given temperature. The gas species concentrations were used to calculate the equilibrium constant for the reformation reaction at each pressure. Figure 2.3 shows that the equilibrium constant $\left(K_{e q, r}\right)$ is independent of the pressure and is described by an Arrhenius function:

$$
K_{e q, r}=\beta_{\text {prex }} \exp \left(-\frac{E_{a}}{R T}\right)
$$

Here, the pre-exponential factor $\beta_{\text {prex }}$ and activation energy $E_{a}$ are constants $\left(1.362 \mathrm{e}+013 \mathrm{~atm}^{-2}\right.$ and $2.246 \mathrm{e}+05 \mathrm{~J} / \mathrm{mol}-\mathrm{K}$, respectively).

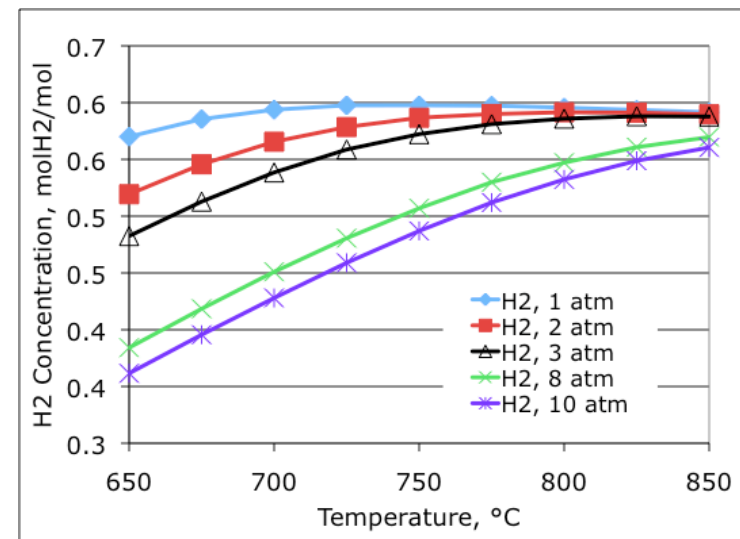

(a)

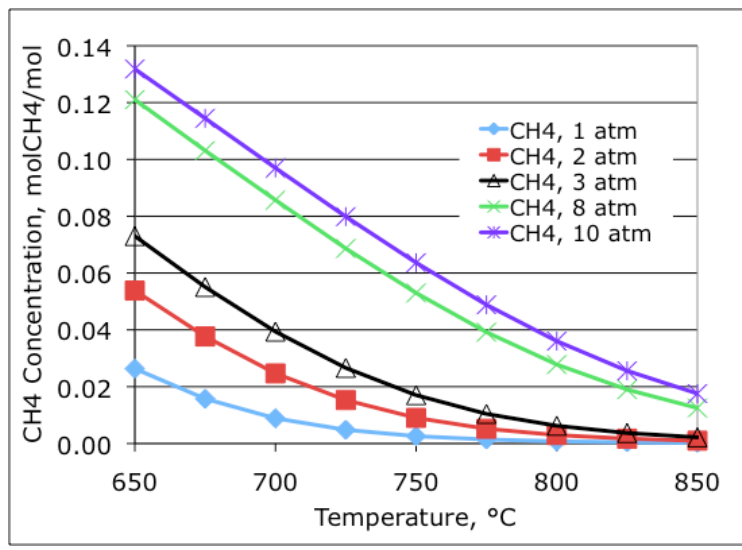

(b)

Figure 2.2. Equilibrium Concentrations of a) Methane and b) Hydrogen Based on Input Gas Mixture of $26.3 \% \mathrm{H}_{2}, 49.3 \% \mathrm{H}_{2} \mathrm{O}, 2.9 \% \mathrm{CO}, 4.4 \% \mathrm{CO}_{2}$, and $17.1 \% \mathrm{CH}_{4}$

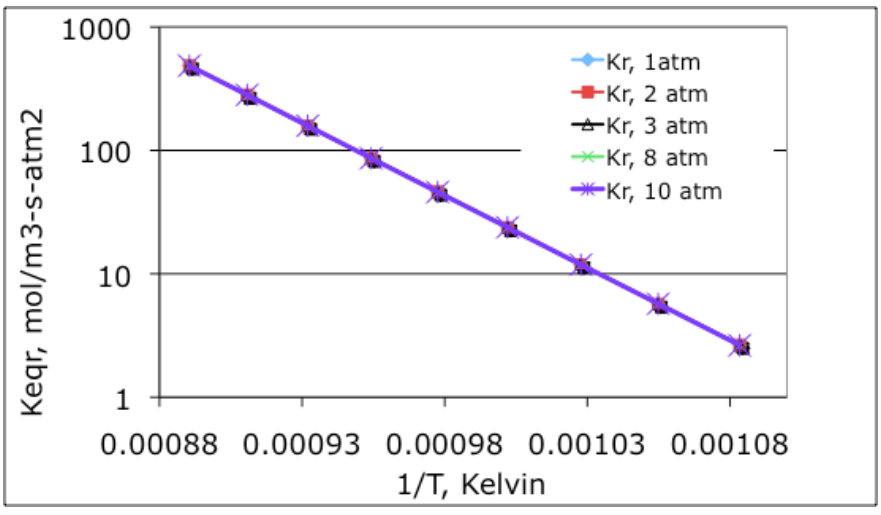

Figure 2.3. Equilibrium Constant for the Steam-Methane Reformation Reaction, $\mathrm{mol} / \mathrm{m}^{3}-\mathrm{s}-\mathrm{atm}^{2}$ 
Noting that the equilibrium constant for this reaction is

$$
K_{e q, r}=\frac{k_{r f}}{k_{r b}}=\frac{P_{C O} P_{H_{2}}^{3}}{P_{\mathrm{CH}_{4}} P_{\mathrm{H}_{2} \mathrm{O}}}
$$

where $k_{r f}$ and $k_{r b}$ are the forward and backward steam reforming constants, respectively, and the $P_{i}$ are the gas specie partial pressures in atm. Then the volumetric reaction rate, in terms of moles of methane reacted per time, was written by Lehnert as

$$
R_{r}=k_{r f}\left(P_{\mathrm{CH}_{4}} P_{\mathrm{H}_{2} \mathrm{O}}\right)-k_{r b}\left(P_{C O} P_{\mathrm{H}_{2}}^{3}\right) \mathrm{mol} / \mathrm{m}^{3}-\mathrm{s}
$$

The first-order dependence on methane pressure in this rate expression is consistent with much of the literature data for testing pressures up to $41 \mathrm{~atm}$, as noted by Lee et al. (1990). It is also consistent with the earlier rate expression derived from testing at PNNL by King and coworkers (2005). The King relation is provided here for convenience:

$$
-r_{C H_{4}}\left(\mathrm{~mol} / \mathrm{g}_{\mathrm{cat}} \mathrm{s}\right)=2.188 \times 10^{8} \exp \left(\frac{-E_{a}}{R T}\right) C_{\mathrm{CH}_{4}} C_{\mathrm{CO}_{2}}^{-0.0134} \mathrm{~mol} / \mathrm{gm}_{\mathrm{cat}^{-}} \mathrm{s}
$$

The King relation accounted for the forward reaction only and was expressed in units of mol/gmcat-s with concentrations in units of $\mathrm{mol} / \mathrm{cc}$. An Arrhenius parity factor $\left(K_{f}\right)$ applied to both the forward and backward reactions places the updated rate expression in agreement with the King relation for the temperature range and atmospheric pressure:

$$
K_{f}=\beta_{f} \exp \left(\frac{E_{f}}{R T}\right)
$$

The result is an overall rate expression that correctly accounts for the pressurization effect on the kinetics and includes a term for the backward reaction, which becomes important when near equilibrium. This rate expression is then written as

$$
R_{r}=K_{f}\left[C_{0} \exp \left(-\frac{E_{a}}{R T}\right) P_{C_{4}} P_{H_{2} O}-C_{2} P_{C O} P_{H_{2}}^{3}\right]
$$

The ratio of the constants $C_{0}$ and $C_{2}$ is equal to $\beta_{\text {prex }}$ in Eq. (2.6). The unit conversion from the King relation to the present expression is included in the pre-exponential for the forward reaction $\left(C_{0}\right)$, which was established as $2.094 \mathrm{e}+09 \mathrm{~mol} / \mathrm{m}^{3}-\mathrm{s}-\mathrm{atm}^{2}$. Subsequently, $C_{2}$ became $1.537 \mathrm{e}-04 \mathrm{~mol} / \mathrm{m}^{3}-\mathrm{s}-\mathrm{atm}^{4}$. Because data used to derive the King relation were collected under atmospheric conditions, and it is unclear how well the relation holds for operating pressures of several atmospheres, the parity factor $\left(K_{f}\right)$ was set to a constant value of unity for the present work.

\subsection{Fuel Gas Composition}

The composition of coal syngas depends in part upon the gasifier type. Hydrogen compositions can range from about $30 \%$ to over $50 \%$ depending on subjection of the syngas to water-gas shift, $\mathrm{CO}_{2}$ removal, hydrogen separation, and desulphurization processes (Gemmen and Trembly 2006, Pettniau et 
al. 2005). Many of these processes result in fuel compositions containing very little methane. But, for large stacks whose maximum temperatures can become very large (Recknagle et al. 2006, 2007a,b), a concentration of methane in the fuel stream is desirable. The reformation of methane with steam is an endothermic reaction that, when reformed on the cell, decreases the net heat load and could possibly have a positive effect on the temperature distribution within the stack. For the present work the coal gas was to be delivered from a catalytic gasifier to the anode with the following composition: $16 \% \mathrm{H}_{2}, 22 \% \mathrm{CO}_{2}$, $38 \% \mathrm{H}_{2} \mathrm{O}, 18 \% \mathrm{CH}_{4}, 5 \% \mathrm{CO}$, and $1 \% \mathrm{~N}_{2}$. The methane content in this fuel gas provided substantial on-cell reformation cooling and enabled the effect on stack performance to be examined.

\subsection{Stack Model Geometry}

The model geometry was a three-dimensional representation of a generic cross-flow, $20 \times 20-\mathrm{cm}$ planar SOFC stack. The footprint for the basic stack geometry is shown in Figure 2.4. The model was composed of 56,788 computational elements and included 1- and 2-mm-tall fuel and air flow channels, respectively, 0.66-mm thick PEN, 1-mm (40 mil) thick separator/interconnect plate, and 0.2-mm thick by 6-mm-wide glass-ceramic seals at the stack perimeter. The computational grid used within the active area (for the baseline model) consisted of 40 elements in both the $\mathrm{X}$ and $\mathrm{Y}$ planar coordinates.

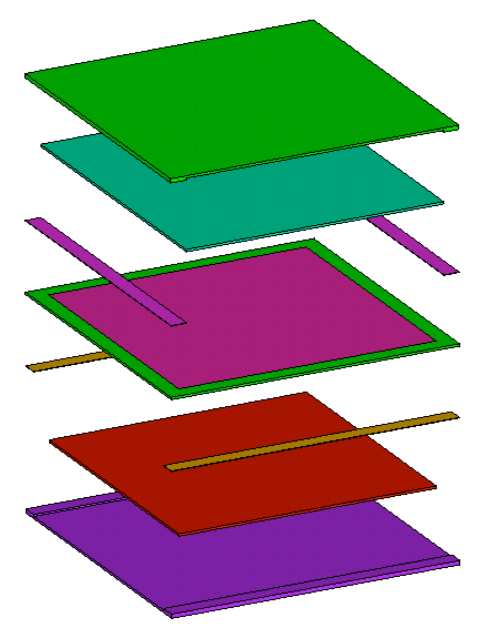

Figure 2.4. Exploded Assembly of the Baseline Stack Model Including (bottom to top) Lower (half-thickness) Separator Plate, Cathode Flow Region/Interconnect, Lower Seal, Cell, Upper Seal, Anode Flow Region/Interconnect, and Upper (half thickness) Separator Plate

\subsection{Boundary Conditions}

The model was constructed to represent a single repeating cell unit at the midlevel of a large, multiple-cell stack where thermal gradients in the vertical direction were assumed small; thus, cyclic boundaries were used at the top and bottom surfaces of the model to represent this condition. The cyclic condition was also reflected in the model geometry via the thickness of the separator plate, which was split with half on top and half on the bottom. It was assumed that the stack was not insulated and was operating within an enclosure with an air gap between the stack and enclosure walls. The model geometry included the stack and manifolds. Heat transfer from the stack to the air gap and enclosure was calculated using reference gap and enclosure temperatures and calculated local thermal resistances accounting for both natural convection and radiation. Reference temperature for the gap was assumed 
equal to the inflowing cathode and anode gases, while the enclosure temperature was a constant $677^{\circ} \mathrm{C}$ $(950 \mathrm{~K})$. Constant mass inflow boundaries were used for the air and fuel streams. The inflowing gas stream temperatures and cell voltages were adjusted to achieve area-weighted average cell temperature and current density of $750^{\circ} \mathrm{C}$ and $0.6 \mathrm{~A} / \mathrm{cm}^{2}$, respectively. Because all cases simulated stack operation at the same average temperature and current density, differences in output power, net heat load, and maximum temperature were attributable to pressurization and reformation rates. Subsequently, the thermal and electrical performance of each case could be compared directly. In the simulations, the iterative solutions for all cases were well converged with respect to mass, momentum, energy, chemistry, and electrochemistry.

\subsection{Electrochemical Performance and Material Properties}

For these analyses, the electrochemical performance of a cell operating on the fully pre-reformed fuel was taken to be a conservative $0.68 \mathrm{~V}$ at $0.60 \mathrm{~A} / \mathrm{cm}^{2}$ with $75 \% / 15 \%$ fuel/air utilizations at an average cell temperature of $750^{\circ} \mathrm{C}$. In the electrochemistry model, the Butler-Volmer parameters were set to

$$
\alpha_{\mathrm{BV}}=0.6, \mathrm{k}_{\mathrm{BV}}=150,000 \mathrm{~A} / \mathrm{cm}^{2} \text {, and } \mathrm{E}_{\mathrm{act}, \mathrm{BV}}=118,000 \mathrm{~J} / \mathrm{mole}
$$

and anode, electrolyte, and cathode thicknesses were 600,10 , and 50 microns, respectively. The porosity of the anode and cathode was $30 \%$, and the tortuosity was assumed as 2.5 for both electrodes. Thermal properties used in the model are summarized in Table 2.1. Improved electrochemical performance would decrease the heat load, creating a more favorable thermal management scenario. For this work a conservative approach was taken.

Table 2.1. Thermal Properties Used in the Simulations

\begin{tabular}{lccc}
\hline \multicolumn{1}{c}{ Material } & $\begin{array}{c}\text { Density } \\
\left(\mathrm{kg} / \mathrm{m}^{3}\right)\end{array}$ & $\begin{array}{c}\text { Thermal Conductivity } \\
(\mathrm{W} / \mathrm{m}-\mathrm{K})\end{array}$ & $\begin{array}{c}\text { Specific Heat } \\
(\mathrm{J} / \mathrm{kg}-\mathrm{K})\end{array}$ \\
\hline \multicolumn{1}{c}{$\begin{array}{c}\text { Gases } \\
\text { (air, fuel) }\end{array}$} & $\begin{array}{c}\text { Ideal gas } \\
\rho=\rho(\mathrm{T})\end{array}$ & $\begin{array}{c}\text { Multicomponent mass } \\
\text { weighted }\end{array}$ & $\begin{array}{c}\text { Multicomponent mass } \\
\text { weighted }\end{array}$ \\
PEN & 4300 & 3 & 0.06 (steady) \\
441-SS separator plates & 7700 & 26.3 & 0.08 \\
Seal (glass) & 2800 & 1.05 & 0.06 \\
Cathode flow space (effective) & Same as cathode air & $\begin{array}{c}13(\text { half that of } \mathrm{I} / \mathrm{C} \\
\text { uniform channel/rib pitch) }\end{array}$ & Same as cathode air \\
Anode flow space (effective) & Same as anode fuel & 9.1 (nickel mesh) & Same as anode fuel \\
\hline
\end{tabular}

\subsection{Simulation Cases}

In the above model development, the zero-dimension point behavior of the electrochemistry, gas composition, and pressurization was examined. Within a SOFC stack we are concerned with spatial variations as well as local conditions. The spatial variations are generally preferred to be small for optimal thermal-electrical and thermal-mechanical performance. Within the $20 \times 20\left(400 \mathrm{~cm}^{2}\right)$ cross-flow stack examined here, ample area exists across the cell for conditions to vary. This way the spatial variations can be predicted and analyzed. In the cases examined here, operating pressures varied from 1 to $10 \mathrm{~atm}$, and two reformation rates differing by a factor of 10 were considered. 



\subsection{Results - Stack Performance}

\subsection{Grid Refinement Study}

Validation data do not exist in the literature for this specialized mode of stack operation that includes pressurization and on-cell reforming. Because no validation data were available, a grid refinement study was conducted to test the solution for grid-independence. To test the computational mesh, the resolution of baseline model was doubled to establish a "refined mesh" case. Solutions from the baseline and refined mesh cases were compared. Distributions of temperature, hydrogen mass concentration, and current density from the refined and baseline cases were practically identical. These results are shown in the appendix. Because the solutions were the same, the selected computational mesh density was deemed suitable for the simulations and increased mesh resolution not required.

\subsection{Effect of Pressurization}

The operating pressure has competing effects on reformation that increase the methane conversion rate while also increasing the equilibrium methane concentration. Results of these effects are shown by graphs plotted along an anode-side gas streamline, with the leading edge at left, passing through the point of highest temperature on the cell, and exiting at right. Figure 3.1a shows methane composition across the anode as a function of operating pressures from 1 to $10 \mathrm{~atm}$. The leftmost monitoring location was $2.5 \mathrm{~mm}$ downstream of the cell's leading edge; thus, some methane would have been converted upstream of this location. The atmospheric case had the lowest reformation rate and thus the highest methane concentration at this location near the leading edge of the cell. Along the cell length, the methane was converted within a shorter distance in the lower-pressure cases (1 and $2.5 \mathrm{~atm}$ ) and consumed over longer distances with increasing pressure due to decreased local temperatures. Within about $13 \mathrm{~cm}$, the methane concentration in all cases had vanished as the reformation was taken to completion. The hydrogen concentration was complimentary (to the methane) with generally lower concentrations in the lowerpressure cases near the leading edge. The concentration increased along the first $30-40 \%$ of the cell as more methane was converted, before decreasing again due to consumption by electrochemical oxidation. The hydrogen concentration then tailed off to the same exit concentration in each case as the designated $75 \%$ fuel utilization was reached (Figure $3.1 \mathrm{~b}$ ). Figure 3.1 shows inflections in the methane and hydrogen concentrations near the leading edge of the anode depending on operating pressure. This occurred because competing effects of increasing pressure increased the reformation rate and increased the electrical efficiency, resulting in decreased heat load and altered temperature distributions. The cell temperature differences along the anode were decreased for operating pressures above 2.5 atm as electrochemical efficiency increased and heat load decreased with increased operating pressure (Figure 3.2a). The temperatures plotted in the figure were normalized by the maximum of the 1 atm case $\left(T_{0}\right)$ to show the relative differences in $\Delta \mathrm{T}$ and maximum temperature. Coinciding with the methane and hydrogen concentrations was an inflection in temperatures. This is illustrated in Figure 3.2b, which plots temperatures from each operating pressure case at the same anode location $2.5 \mathrm{~mm}$ from the leading edge. Additional simulation cases of 1.3 and 1.75 atm help locate the inflection point. The increased electrochemical efficiency reflected by the temperature profiles is seen more explicitly by the current density (Figure 3.3), which increased near the fuel inlet and decreased downstream for pressures greater than $2.5 \mathrm{~atm}$, resulting in more uniform distribution. 


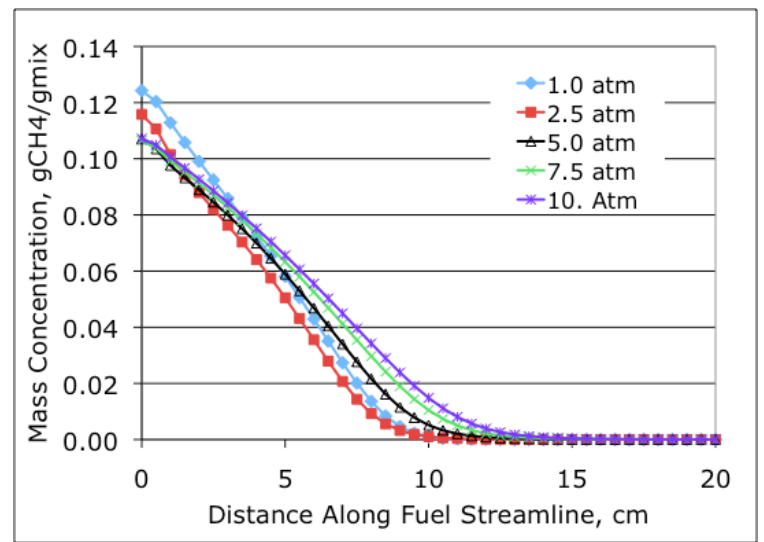

(a)

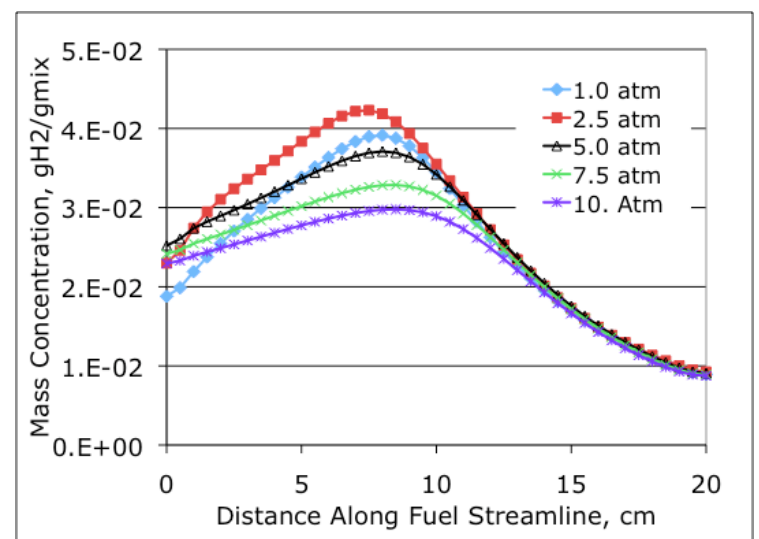

(b)

Figure 3.1. Pressurized Stack Simulation Results for Internal Reforming and Operating Pressures of 1 to $10 \mathrm{~atm}$ and Profiles of Mass Concentration of a) Methane and b) Hydrogen

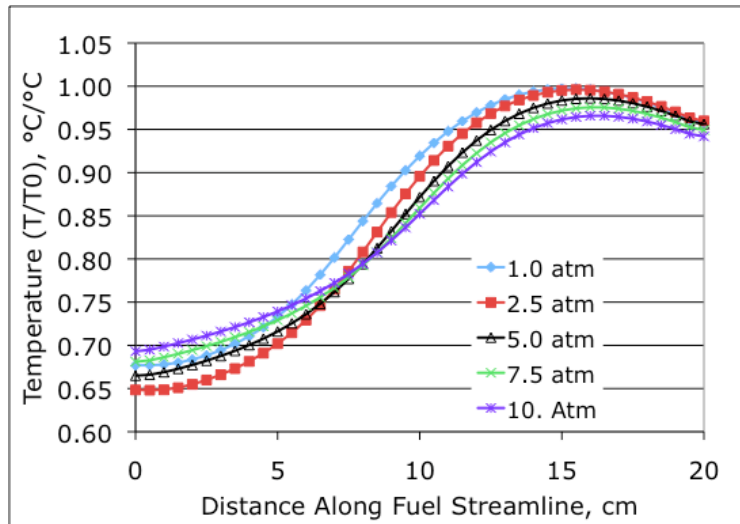

(a)

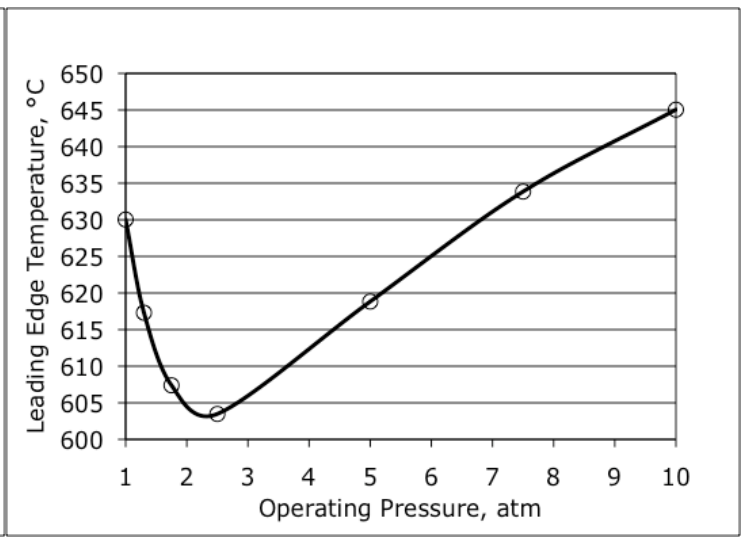

(b)

Figure 3.2. Pressurized Stack Simulation Results for Internal Reforming and Operating Pressures of 1 to $10 \mathrm{~atm}$ and Profiles of a) Normalized Temperature $\left({ }^{\circ} \mathrm{C} /{ }^{\circ} \mathrm{C}_{\max }\right)$ and b) Anode Temperature $2.5 \mathrm{~mm}$ downstream of the leading edge $\left({ }^{\circ} \mathrm{C}\right)$

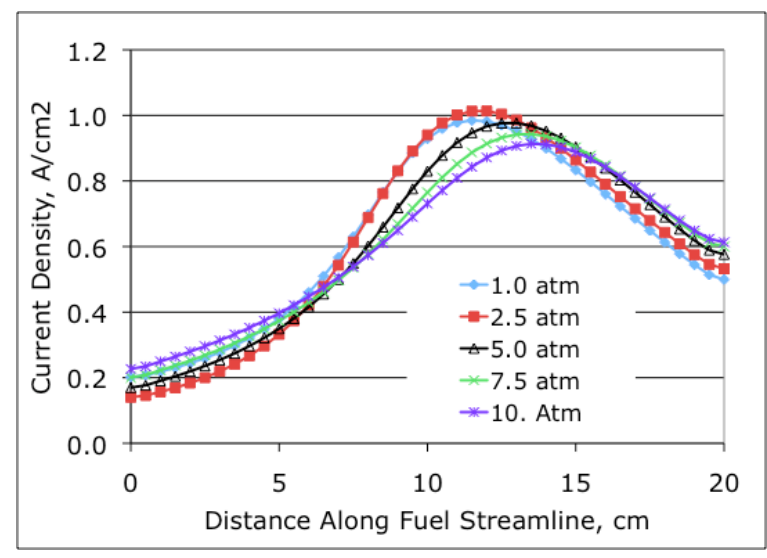

Figure 3.3. Pressurized Stack Simulation Results for Internal Reforming and Profiles of Electrical Current Density Along a Fuel Stream Line on the Anode for Pressures of 1-10 atm 
As pressure was increased from 1 to $5 \mathrm{~atm}$, the consumption of methane increased, leading to more localized reaction cooling and decreased local temperature. As an increasing amount of methane was consumed with increasing pressure, the concentration was reduced such that further increases in reformation rate could not be supported and reached a maximum at $7.5 \mathrm{~atm}$. Figure $3.4 \mathrm{a}$ shows this effect with the methane concentration and reforming rate changing opposite one another. Examination of these rates plotted along a fuel stream line (Figure 3.4b) shows the leading edge rates increasing with pressure to 7.5 atm and steeply decreasing in the high-pressure reforming rates as the methane concentration was decreased. This was followed by rebounding rates within the first third of the cell length and a tailing off of the rates as the methane was fully converted near the exit at the right. The lower-pressure cases had a greater mid-cell rate increase because of higher local temperatures. The results illustrate the sensitivity of the scalar distributions within the stack to increased operating pressure and electrical efficiency.
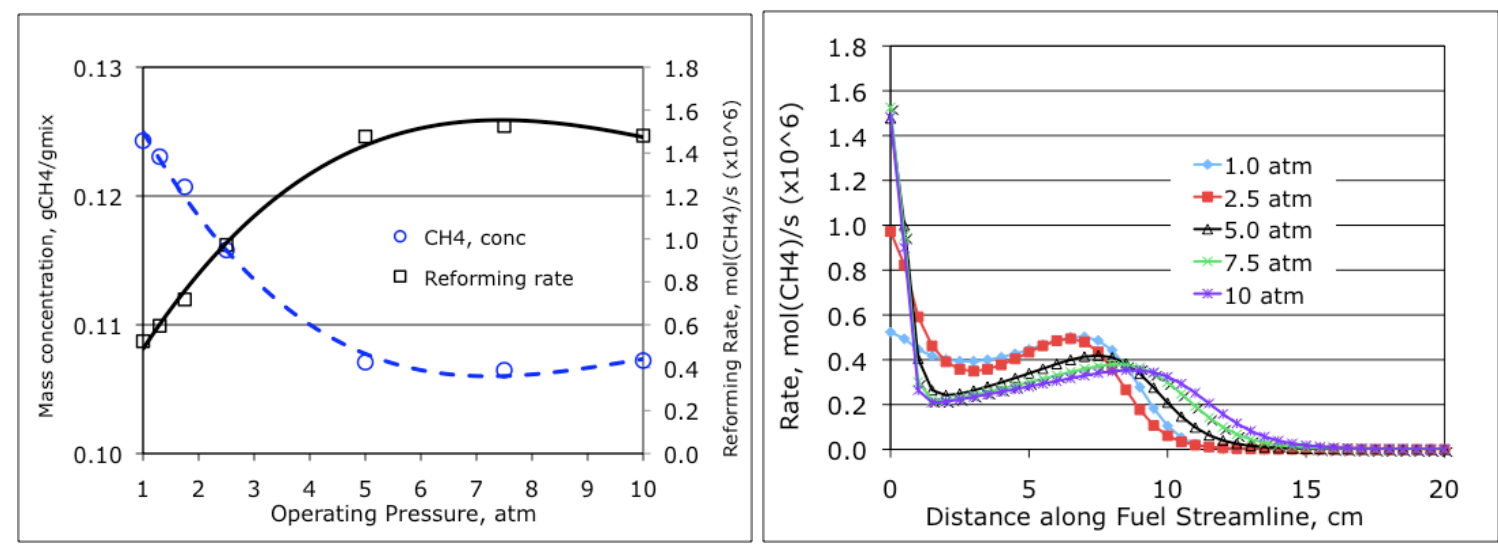

Figure 3.4. Pressurized Stack Simulation Results for Internal Reforming and Profiles; a) Methane Mass Concentration and Reforming Rate $\left(\mathrm{mol}\left(\mathrm{CH}_{4}\right) / \mathrm{s}\right.$ ) (on the anode $2.5 \mathrm{~mm}$ downstream of the leading edge), for Operating Pressures of 1-10 atm, and b) Reforming Rate Along a Fuel Stream Line on the Anode for Pressures of 1-10 atm

Cell voltages for these cases are provided in Table 3.1, showing monotonically increasing electrical performance with increased pressure for each of the $750{ }^{\circ} \mathrm{C}, 0.6 \mathrm{~A} / \mathrm{cm}^{2}$ cases. The voltage was somewhat higher for the fast reforming cases at lower pressures because of the elevated Nernst potential caused by lower methane and higher hydrogen concentrations over more of the cell area and virtually the same for pressures of 7.5 and $10 \mathrm{~atm}$.

\subsection{Effect of Reformation Activity}

The methane conversion activity for any given Ni-YSZ anode is subject to variations caused by aging, sintering, and the percentage of $\mathrm{Ni}$ in the cermet, to name a few. No baseline activity has been established for comparison. For this work we assume that the baseline, or standard, reformation rate is that determined by King et al. (2005). Temperature profiles in Figure 3.5 compare results from cases using the standard rate and a rate 10 times slower. For a 2.5 atm operating pressure, the minimum and maximum temperatures decreased when the slower rate was used. When the operating pressure was increased to $10 \mathrm{~atm}$, the benefit gained by a slower reforming rate at lower pressure diminished. The temperature profiles of the slower and standard cases were nearly identical. The effect of increased electrochemical performance and decreased heat load associated with operation at $10 \mathrm{~atm}$ dominated the difference in endothermic effect due to the standard and slower methane conversion rates. The potential benefit to the thermal performance of the slower reforming rate was achieved with pressurized operation. 
Table 3.1. Predicted Thermal and Electrical Performance of 20x20-cm Generic Cross-Flow Stack Cases with on-Cell Methane Reformation and Pressurized Operation (average cell temperature $750^{\circ} \mathrm{C}$, average current density $0.6 \mathrm{~A} / \mathrm{cm}^{2}$ )

\begin{tabular}{|c|c|c|c|c|c|c|c|c|c|}
\hline \multirow{2}{*}{$\begin{array}{c}\text { Case } \\
\text { Pressure, } \\
\text { atm }\end{array}$} & \multirow[b]{2}{*}{$\begin{array}{c}\text { Cell } \\
\text { Voltage }\end{array}$} & \multicolumn{4}{|c|}{ Temperature, ${ }^{\circ} \mathrm{C}$} & \multirow{2}{*}{$\begin{array}{c}\text { Heat } \\
\text { Load } \\
\text { W }\end{array}$} & \multicolumn{3}{|c|}{ Heat Out, W } \\
\hline & & $\mathrm{T}_{\text {inflow }}$ & $\mathrm{T}_{\min }$ & $\begin{array}{l}\mathrm{T} / \mathrm{T}_{\max } \\
{ }^{\circ} \mathrm{C} /{ }^{\circ} \mathrm{C}\end{array}$ & $\Delta \mathrm{T} / \Delta \mathrm{T}_{\max }$ & & Qair & Qfuel & Qwalls \\
\hline \multicolumn{10}{|c|}{ Standard Reforming Rate Cases } \\
\hline $1.0(\mathrm{std})$ & 0.653 & 649 & 581 & 1.000 & 0.922 & 92 & -56 & -14 & -22 \\
\hline $2.5(\mathrm{std})$ & 0.678 & 674 & 587 & 0.999 & 1.000 & 83 & -54 & -14 & -15 \\
\hline $5.0(\mathrm{std})$ & 0.690 & 681 & 613 & 0.989 & 0.924 & 78 & -51 & -14 & -13 \\
\hline 7.5 (std) & 0.717 & 687 & 630 & 0.978 & 0.847 & 76 & -50 & -13 & -13 \\
\hline $10.0(\mathrm{std})$ & 0.721 & 690 & 645 & 0.968 & 0.785 & 75 & -50 & -13 & -12 \\
\hline \multicolumn{10}{|c|}{ Slower Reforming Rate Cases } \\
\hline 1.0 (slow) & 0.628 & 656 & 657 & 0.954 & 0.593 & 106 & -72 & -10 & -24 \\
\hline 2.5 (slow) & 0.667 & 674 & 612 & 1.000 & 1.000 & 84 & -54 & -14 & -16 \\
\hline 5.0 (slow) & 0.684 & 682 & 619 & 0.999 & 0.976 & 78 & -51 & -14 & -13 \\
\hline 7.5 (slow) & 0.716 & 688 & 633 & 0.992 & 0.917 & 76 & -50 & -13 & -13 \\
\hline 10.0 (slow) & 0.721 & 691 & 649 & 0.981 & 0.840 & 75 & -50 & -13 & -12 \\
\hline
\end{tabular}

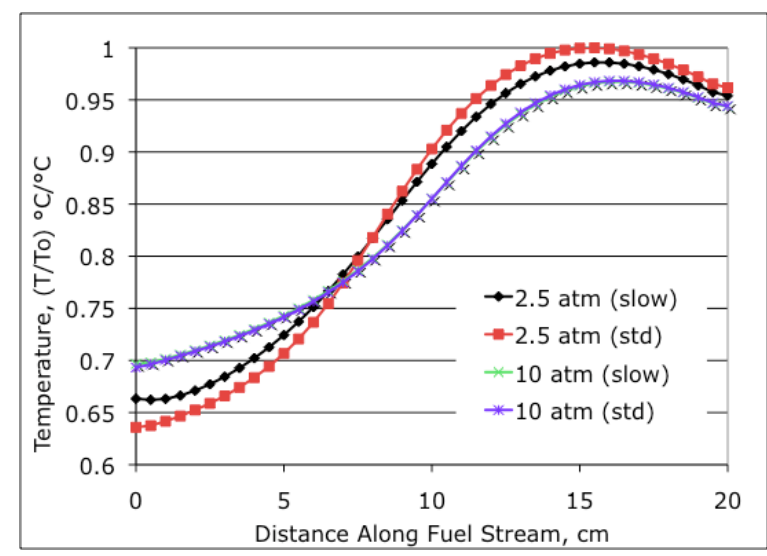

Figure 3.5. Axial Temperature Distributions for Internal Reforming Cases with Standard Methane Conversion Activity and for 10 Times Slower than Standard Activity at Operating Pressures of 2.5 and 10 atm

The thermal and electrical performance predictions are summarized in Table 3.1. The on-cell reforming stack simulations predicted improved electrical performance for both standard and slowed reforming rate cases as operating pressure was increased with matching performance above $7.5 \mathrm{~atm}$. The inflowing gas temperature for both the standard and slowed reforming rate cases increased similarly with increased electrical performance (and decreased heat load). The overall thermal performance, as indicated by $\Delta \mathrm{T}$ and $\mathrm{T}_{\max }$, was generally improved for operating pressures above $2.5 \mathrm{~atm}$. The slower reforming case operated at $1 \mathrm{~atm}$ had incomplete methane conversion, resulting in a much higher heat load relative to the standard reforming rate case, and an apparently improved thermal performance. 
However, the incomplete reformation and remaining methane in the fuel decreased the Nernst potential and electrical performance. At $10 \mathrm{~atm}$ for both reforming rates, $\mathrm{T}_{\max }$ had decreased by about $4 \%, \Delta \mathrm{T}$ had decreased by $28 \%$, and the cell voltage increased by $10 \%$ compared with the atmospheric fast-reforming case. 



\subsection{Conclusions}

This work has developed constitutive submodels that couple the electrochemistry, reforming, and pressurization to yield an improved capability of the modeling tool for prediction of SOFC stack performance. The capability was demonstrated with simulations of large stacks operating on methane-rich fuel under pressurized and non-pressurized conditions.

The electrochemistry model was advanced to characterize the increased SOFC performance due to diminished activation polarization. The Nernst potential is also increased with pressure and when augmented by decreased polarization provided increased cell voltage and stack power.

A new methane conversion rate expression was developed by this work. The effects of pressure to accelerate the forward reaction kinetics and increase the methane concentration for the equilibrium case were considered. The result was an expression of the overall conversion rate that correctly accounts for the pressurization effect on the kinetics as well as the reverse reaction.

The electrochemistry and methane reforming submodels were applied in a 3-dimensional, 20x20-cm cross-flow stack model to demonstrate the capability to evaluate the changes to distributions of fuel, temperature, current density, and pressure within large area stacks with internal reforming and varied operating pressures. Cases of operating pressures ranging from 1 to $10 \mathrm{~atm}$ and two reformation rates differing by a factor of 10 were simulated. The predictions showed consistently increased electrical performance, for both reforming rate cases with increased operating pressure. The overall thermal performance, as indicated by maximum temperature and temperature difference, was generally improved for operating pressures above $2.5 \mathrm{~atm}$. At $10 \mathrm{~atm}$, for both reforming rates, the maximum temperature had decreased by about $4 \%$, the temperature difference had decreased by $28 \%$, and the cell voltage increased by $10 \%$ compared to the atmospheric fast reforming case.

The results indicate that pressurization could be of benefit to electrical and thermal performance of a stack with internal reforming for pressures over $2.5 \mathrm{~atm}$, and the potential thermal benefit of a slower reforming rate may be achieved with pressurized operation. 



\subsection{References}

Chick LA, JW Stevenson, KD Meinhardt, SP Simner, JE Jaffe, and RE Williford. 2000. "Modeling and Performance of Anode-Supported SOFC.” 2000 Fuel Cell Seminar - Abstracts, pp. 619-622.

Chick LA, RE Williford, JW Stevenson, CF Windisch Jr, and SP Simner. 2002. "Experimentally Calibrated, Spreadsheet-Based SOFC Unit-Cell Performance Model.” 2002 Fuel Cell Seminar Abstracts. Palm Springs, California.

Gemmen RS and J Trembly. 2006. "On the mechanisms and behavior of coal syngas transport and reaction within the anode of a solid oxide fuel cell." Journal of Power Sources 161:1084-1095.

Iwata M, T Hikosaka, M Morita, T Iwanari, K Ito, K Onda, Y Esaki, Y Sakaki, and S Nagata. 2000. "Performance analysis of planar-type unit SOFC considering current and temperature distributions." Solid State Ionics 132:297-308.

Khaleel MA. 2005. "Finite Element SOFC Analysis with SOFC-MP and MSC.Marc/Mentat-FC." Proceedings of Sixth Annual SECA Workshop. NETL, Morgantown, West Virginia. Available at www.netl.doe.gov/publications/proceedings/05/SECA_Workshop/SECAWorkshop05.html.

Khaleel MA, Z Lin, P Singh, W Surdoval, and D Collins. 2004. "A Finite Element Analysis Modeling Tool for Solid Oxide Fuel Cell Development: Coupled Electrochemistry, Thermal, and Flow Analysis in Marc.” J. Power Sources, 130[1-2]:136-148.

Keegan K, M Khaleel, L Chick, K Recknagle, S Simner, and J Deibler. 2002. "Analysis of a Planar Solid Oxide Fuel Cell-Based Automotive Auxiliary Power Unit." Proceedings of Society of Automotive Engineers Congress 2002-01-0413.

Kim JW, AV Virkar, KZ Fung, K Metha, and S Singhal. 1999. "Polarization Effects in Intermediate Temperature, Anode-Supported Solid Oxide Fuel Cells.” J. Electrochem. Soc. 146:69-78.

King DL, Y Wang, Y Chin, Y Lin, H Roh, and R Romiarek. 2005. "Controlling Activity and Stability of Ni-YSZ Catalysts for On-Anode Reforming." Presented at SECA Core Technology Program Review Meeting, Tampa, Florida.

Lee AL, RF Zabranski, and WJ Huber. 1990. "Internal Reforming Development for Solid Oxide Fuel Cells." Ind. Eng. Chem. Res. 29:766-773.

Lehnert W, J Meusinger, and F Thom. 2000. "Modeling of gas transport phenomena in SOFC anodes." Journal of Power Sources 87:57-63.

Roine A. 2002. "Outokumpu HSC Chemistry Version 5.1.” Outokumpu Research Oy Information Service, Pori, Finland.

Minh N. 2002. "Solid Oxide Fuel Cell Hybrid System for Distributed Power Generation.” Texas Hybrid Meeting, Galvestion. 
Nagata S, A Momma, T Kato, and Y Kasuga. 2001. "Numerical analysis of output characteristics of tubular SOFC with internal reformer." Journal of Power Sources 101:60-71.

Pettniau A, A Orsini, and C Amorino. 2005. "Sotacarbo R\&D Project for Hydrogen Production from Coal and $\mathrm{CO}_{2}$ Removal." Second International Conference on Clean Coal Technologies for our Future. Castiadas Sardinia, Italy.

Recknagle KP, RE Williford, LA Chick, DR Rector, and MA Khaleel. 2003. "Three-dimensional thermo-fluid electrochemical modeling of planar SOFC stacks.” J. Power Sources 113:109-114.

Recknagle KP, P Singh, LA Chick, and MA Khaleel. 2004. "Modeling of SOFC Stacks with On-Cell Steam-Methane Reformation at PNNL.” PNNL-SA-43248, Proceedings of the Fuel Cell 2004 Seminar, San Antonio, Texas.

Recknagle KP, ST Yokuda, and MA Khaleel. 2006. "Analysis of Percent On-Cell Reformation of Methane in SOFC Stacks: Thermal, Electrical, and Structural Analysis." PNNL-15787, Pacific Northwest National Laboratory, Richland, Washington.

Recknagle KP, BJ Koeppel, X Sun, MA Khaleel, ST Yokuda, and P Singh. 2007. “Analysis of Percent On-Cell Reformation of Methane in SOFC Stacks and the Effects on Thermal, Electrical, and Mechanical Performance.” PNNL-SA-53556, Pacific Northwest National Laboratory, Richland, Washington.

Journal of the Electrochemical Society 5(1):357-361.

Recknagle KP, CL Rakowski, BJ Koeppel, W Liu, and MA Khaleel. 2007. "Analysis and Optimization of Thermal and Electrical Performance of Large Scale SOFC Stacks." PNNL-17099, Pacific Northwest National Laboratory, Richland, Washington.

Sawata A and K Tsuneyoshi. 1990. "Oxygen chemical potential profile in a solid oxide fuel cell and simulation of electrochemical performance.” Solid State Ionics 40/41:415-420.

Singhal SC. 2000. “Advances in solid oxide fuel cell technology.” Solid State Ionics 135:305-313.

Williford RE, LA Chick, GD Maupin, SP Simner, and JW Stevenson. 2003. "Diffusion Limitations in the Porous Anodes of SOFCs.” J. Electrochemical Soc. 150(8):A1067-A1072. 


\section{Appendix}

Analysis of the Computational Mesh 



\section{Appendix}

\section{Analysis of the Computational Mesh}

An analysis of the computational mesh to determine the suitability for use in the simulations was performed in a grid refinement exercise. The resolution of baseline model was doubled to establish a "refined mesh" case. Solutions from the baseline and refined cases were compared. Distributions of temperature, hydrogen mass concentration, and current density from the refined and baseline cases were practically identical, as shown in Figures A.1 and A.2. Because the solutions were the same, the selected computational mesh density was deemed suitable for the simulations, and increased mesh resolution was not required.

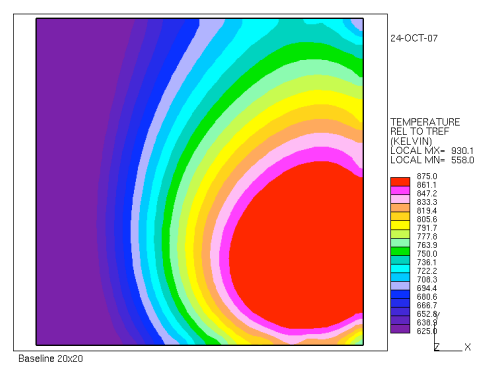

(a)

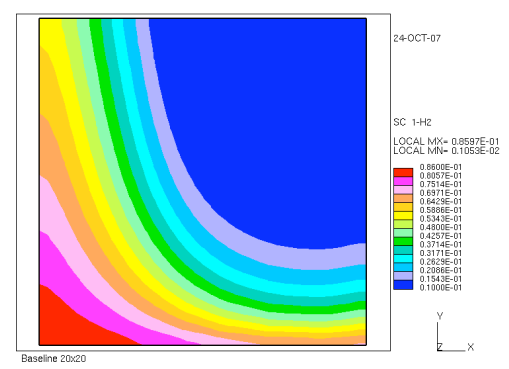

(b)

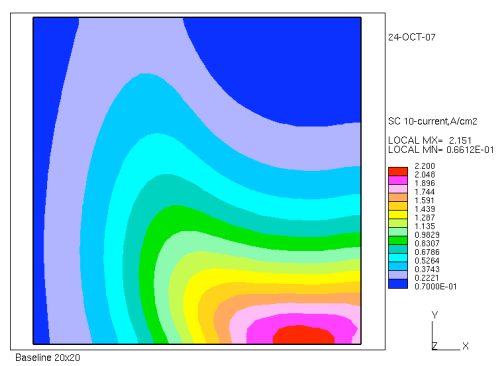

(c)

Figure A.1. Case: 20x20-cm: 30\% Air Utilization, 75\% Fuel Utilization, $\mathrm{K}_{\mathrm{IC}}=26, \mathrm{~T}_{\mathrm{rad}}=677$. Distributions of a) Cell Temperature, b) Hydrogen Mass Concentration, and c) Current Density

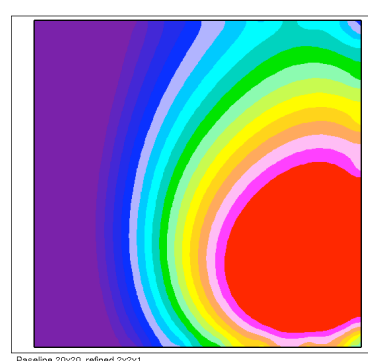

(a)
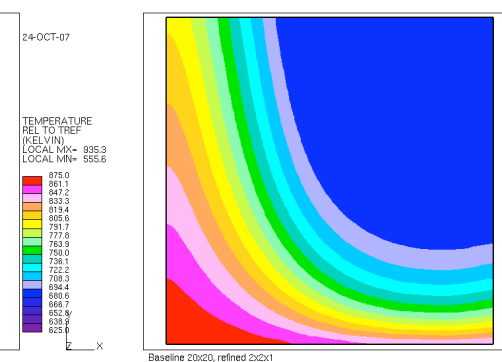

(b)
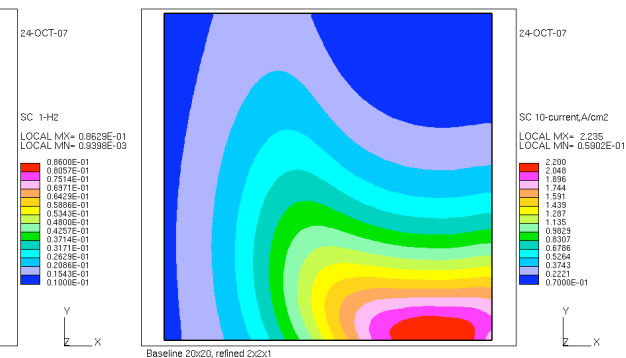

(c)

Figure A.2. Case "Refined-Mesh": 20x20-cm 30\% Air Utilization, 75\% Fuel Utilization, $\mathrm{K}_{\mathrm{IC}}=26$, $\mathrm{T}_{\mathrm{rad}}=677$. Distributions of a) Cell Temperature, b) Hydrogen Mass Concentration, and c) Current Density 




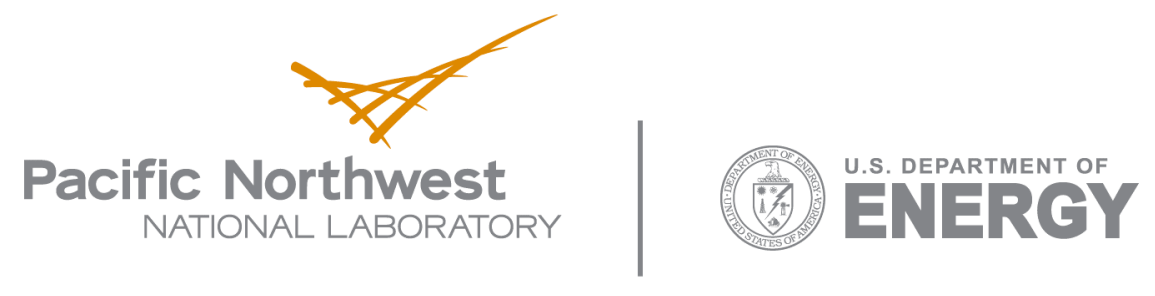

902 Battelle Boulevard

P.O. Box 999

Richland, WA 99352

1-888-375-PNNL (7665)

www.pnl.gov 